\title{
MAN, WOMAN, VIOLENCE AND SAM SHEPARD
}

\author{
ERKEK, KaDIN, ȘidDET
}

Ve SAM SHepard

\section{Abstract}

This article aims to reveal how hard and painful the relationships are between man and woman in Sam Shepard's plays. Shepard's male characters are marked with their using abundant violence on the female characters. The most interesting thing about this situation is his characters' response to this violence. Neither the oppressor shows any sign of remorse, nor does the victim give the impression of suffering. Moreover, both sides seem to revel in such a sadomasochistic relationship.

Excessive reactions and reckless behaviours determine the usual actions of his characters. Shepard tries to find out an existential explanation for the nature of man and woman. He points to the reasons why men tend to escape from home. He does not only criticise the violence and irresponsibility of man but also is angry with the weak females who are treated as a sort of fetish, a material for man either to abuse or enjoy and finally to dispose.

\section{Özet}

Bu makale, Sam Shepard'ın oyunlarında erkek ve kadın arasındaki ilișkilerin ne denli zor ve acılı olduğunu ortaya koymayı amaçlamaktadır. Shepard'ın erkek karakterleri kadın karakterler üzerine uyguladıkları șiddet ile ön plana çıkarlar. Asıl ilginç olan karakterlerinin böyle bir durum karșısında sergiledikleri tavırdır. Șiddet uygulayan bir pișmanlık belirtisi göstermediği gibi, kurbanın acı çektiğine ilișkin bir izlenim de edinmeyiz. Dahası, her iki taraf ta böyle bir karmașık ilișkiden hoșlanır gibi görünür. Așırı tepki ve düșünmeden hareket etme karakterlerin genel tavırlarını ifade eder. Shepard erkek ve kadın doğasına varolușsal bir açıklama getirmeye çalıșır. Erkeklerin neden evden kaçtıkları sorusuna ișaret eder. Sadece erkeklerin șiddet ve sorumsuzluk duygularını eleștirmez, aynı zamanda erkekler tarafından suiistimal edilen, eğlenilen, sonunda atıp kurtulmaya çalıșılan bir tür eșya gibi görünen kadınlara da zayıfıklarından ötürü kızgındır.

\footnotetext{
* Araș.Gör.,Dr., Van Yüzüncü Yıl Üniversitesi Fen-Edebiyat Fakültesi İngiliz Dili ve Edebiyatı Bölümü
} 


\section{INTRODUCTION}

$\mathrm{S}$ hepard is considered one of the leading absurdist playwrights in American drama. The general picture of woman portrayed by absurdist playwrights is a minor one in the society. Shepard's plays are important in exposing to what extent marital violence is experienced in an average American middle class family. Not only are women victim of violence, but also underestimated by the male characters, notably the husbands or fathers. In a typical Shepard play, the past of the mother is hardly known. While the interaction between father and son and their past are clearly expressed, no information is available about the mother. And this is thought to be a reflection of Shepard's inner world.'

Domestic violence is generally seen as a means of control over the physically weak households, particularly women. This is a typical patriarchal attitude at home. However, it has always been kept secret throughout history, but since the 1960s, the feminist movement has helped marital violence to be exposed.

1 James K. Boehnlein, Susan S. Erstling and Landy F. Sparr, "Sam Shepard and the Dysfunctional American Family: Therapeutic Perspectives," American Journal of Psychotherapy, Vol. XLIV, No.4, Oct, 1990, p.572.

2 James Fulcher and John Scott, Sociology, 0xford University Press, 1999, p.155.

${ }^{3}$ Ibid, pp.394-5.
Many people, including some scientists, suggest that there is a close relationship between violence and biology, and they see violence as deriving from innate characteristics. It is not only seen as a male-based attitude but also due to genetic peculiarities. Violent criminals are said to carry extra $Y$ chromosome in their cells. ${ }^{2}$ This is also the case as regards the genetic power in Shepard's plays. Most of his male characters afflict others as well as suffer from such a 'cursed' blood. However, this explanation for violence is not that easy, and of course, this situation is supported by special reasons and social environment in which it is originated.

Three possible explanations thought for domestic violence and sexual abuse are changes in behaviour, redefinition of behaviour and increasing awareness. ${ }^{3}$ Changes in behaviour increase in time and take an unbearable state, as in the example of Beth in Shepard's Lie of the Mind (1985). Beth's husband, Jake becomes 
increasingly jealous of Beth whose behaviours, recalling the existence of another male, come to an unbearable state for him. Redefinition of behaviour means that behaviour once regarded acceptable or slightly mistaken begins to be considered as unacceptable in time. Child beating can be given as an example. As time passes Jake redefines the actions of Beth who is an actress. Increasing awareness occurs when an unacceptable behaviour, held secret for a while, is uncovered after some time. A hidden state is kept secret for a while before it is finally revealed. These 'dark sites' of a family are at last unravelled causing stormy consequences, which epitomizes the deadly secret of the killed and buried baby in Buried Child (1977).

\section{Violence ANd Madness}

In his recent stage plays, such as Fool for Love (1983) and $A$ Lie of the Mind (1985), and his screenplay Paris, Texas (1984), Shepard explores gender conflict. The male characters often beat their female counterparts. They show an increasing violence on women. Shepard has always been fascinated by violence and its traces more or less appear in his almost all plays. In the opening scene of A Lie of the Mind, we are informed that Jake, the husband has beaten his wife, Beth severely and thinks that she is dead; Curse of the Starving Class (1978) opens with a scene just in the wake of the violence of parents; brutality crowds Buried Child in which an incestuous baby has been buried after being strangled; Lee and Austin fight fiercely in True West (1980). Shepard seeks to explore the nature and roots of this violence. Lynda Hart points to a different reason for it and suggests that not only Shepard but Americans in general love violence and they love to see it in plays and films. ${ }^{4}$

There is a physical menace in Shepard's plays and the reader or the audience feels the pressure of violence which is likely to come soon. His characters seem to have a sadistic revelling in this violence. The battle for dominance together with conflicting inner primitive fears are common themes in his most plays. These fears bring about insanity-like behaviours in his characters. Both old and young generations occupy the same

\footnotetext{
${ }^{4}$ Lynda Hart, "Sam Shepard's

Pornographic Visions: Depictions of Women in his Plays," Studies in the
} Literary Imagination 2, 1988, (2), 72. 
space, time and predicaments. Their reactions are more than necessary, and thus they act unduly. The households in his plays seem to be obsessive individuals and mentally ill. And their madness does not occur temporarily, but relapses very often. ${ }^{5}$ His plays show excessive realistic elements, and the realism is replaced by naturalistic violence as the plays progress, notably in Curse of the Starving Class and Buried Child, which earned the playwright an Obie Award and a Pulitzer Prize respectively. Violence, in his plays, is not limited with a single character. His characters show a considerable outrage as much as their power allows them. In this naturalistic environment, each member gets crazy, performing their turn by victimizing the other. Thus each character plays a cruel and a victim role. This vicious circle goes on and on endlessly. There is no a stability in his plays, but violence as a stable element is always there. While certain members afflict other members in the family, they are oppressed by the strangers outside the house. Naturalistic elements crowd his work either from within or outside the family. In the opening stage of Curse of the Starving Class, the mother fries bacon on the stove. And Wesley, the son fills some pieces of broken wood in a wheelbarrow recalling what happened the previous night while lying and keeping watching the dangling model planes over his head:

I was lying there on my back. I could smell the avocado blossoms. I could hear the coyotes ...I could feel the presence of all the people outside, at night, in the dark...Even all the sleeping animals. Dogs. Peacocks. Bulls...I listened like an animal. My listening was afraid. Afraid of sound. Tense. Like any second something could invade me. Some foreigner...Then I heard the Packard coming up the hill...Then I could picture my Dad driving it...My heart was pounding...Feet coming. Feet walking toward the door. Feet stopping. Heart pounding. Sound of door not opening. Foot kicking door. Man's voice. Dad's voice. Dad calling Mom. No answer. Foot kicking. Foot

${ }^{5}$ C. W. E. Bigsby, Modern American Drama, 1945-2000, The Press Syndicate of the University of Cambridge, UK, 2000, 166. kicking harder. Wood splitting. Man's voice. In the night. Foot kicking hard through door. One foot right through door. Bottle crashing. Glass breaking. Fist 
through door. Man cursing. Man going insane. Feet and hands tearing. Head smashing. Man yelling. Shoulder smashing. Whole body crashing. Woman screaming. Mom screaming. Mom screaming for police. Man throwing wood. Man throwing up. Mom calling cops. Dad crashing away. Car door slamming. Ignition grinding...Sound disappearing. No sound. No sight. Planes still hanging. Heart still pounding. No sound. Mom crying soft...Then no sound. Then softly crying... (pp.137-138).

The above speech is openly uttered by a person who really has experienced marital violence and felt every detail of it.

In most of his plays, such as in Fool for Love and A Lie of the Mind, as if "a sadomasochistic passion drives out all other concerns." 6 His plays deal with the tense situations in the American families in which the households are ready to burst out. Although Shepard claims that he is not in favour of violence or masculine macho attitude, consciously or unconsciously he seems to praise it in a way. In an interview with Michiko Kakutani of New York Times in 1984, he makes his own comment and description about it:

I think there is something about American violence that to me is very touching... In full force it's very ugly, but there is also something very moving about it, because it has to do with humiliation. There is some hidden, deeply rooted thing in the Anglo-male American that has to do with inferiority, that has to do with not being a man, and always, continually having to act out some idea of manhood that is invariably violent. This sense of failure runs very deep. ${ }^{7}$

But of course this sense of inferiority cannot justify male violence over female. For Shepard, this violence is caused the male himself, and there is nobody else to blame. ${ }^{8}$ However, some of his male characters accuse their counterparts of being the source of male aggression.
${ }^{6}$ Bigsby, ibid, p.167.

${ }^{7}$ Hart, ibid, p.72.

${ }^{8}$ Hall, Ann C., A Kind of Alaska: Women in the Plays of O'Neill, Pinter, and Shepard, Southern Illinois University Press, Carbondale, 1993, p.95. 
Shepard suggests that the source of violence is not woman as the males claim, but instead, it is the man himself. He thinks that the violence in male characters derives from a lack, a problem inherited in them. Man uses violence in order to make the female obey; in other words, they try to suppress this lack using violence. Ann C. Hall associates this idea with "Lacanian concept of Lack." And this feeling of lack is due to the absence of phallus.

Jacques Lacan differentiates between penis and phallus. He suggests that they are different things. Penis is an organ, and males have it biologically, but phallus means power. Therefore, phallus has nothing to do with penis, and it is possible that both sexes lack phallus. Giving way to the father as the authority, the male is symbolically castrated though he has penis which gives him only a slight claim of power. For example, Shepard's crippled character Bradley, in Buried Child, is a typical male of violence though he is a man with a wooden leg, a missing leg which stands for impotence. On the other hand, female can never possess penis or phallus, that is, the power. As a result, both man and woman each become incapable individuals. ${ }^{10}$

${ }^{9}$ Ibid, pp.94-95.

${ }^{10}$ Charles E. Bressler, Literary Criticism: An Introduction to Theory and Practice, Upper Saddle River, New Jersey, 2003, p.131.
In his plays, notably in Buried Child (1979), Shepard searches for the nature of paternity. He depicts a rather grey picture. The father is cruel, aggressive, dysfunctional and oppressive at the same time. This odd creature is created by the society itself. The men are problematic and do not present a reliable attitude. Although Dodge, the father in Buried Child is weak, old, dysfunctional, and cannot move, he tries to control his family from his sofa where he is stuck. He stands as a semi-dead body, a corpse, as his wife, Halie refers to him: "You sit here day and night, festering away! Decomposing! Smelling up the house with your putrid body! Hacking your head off till all hours of the morning! Thinking up mean, evil, stupid things to say about your own flesh and blood!" (p.76). The brothers, like their father, do not function properly, either. In the family, in which dialogue is impossible, behaviours tell many things: the father is half-live; of the sons, Tilden is halfwit, and Bradley is an amputee, a half-man. Every aspect gives 
a picture of a dead family. This kind of violent masculine attitude is the main cause of destruction in Shepard's families.

\section{Men ANd Woman}

Shepard's most plays are crowded with the clashes of the pairings formed either by a man and a woman or by two men, and his plays seem to exist in a male dominated world in which the women characters are perplexed, or victims of male violence. C.W.E. Bigsby suggests that men are more interesting than women in Shepard's plays since "the real mystery in American life lies between men, not between men and women"11 as is the case in his plays.

Shepard claims that a friendship might occur between two men, and it is possible between a man and a woman, but the second is rather painful and is full of pitfalls, hardships. ${ }^{12}$ To give an example, in Fool for Love, the union of Eddie and May does not seem possible. This impossibility comes both from an incestuous origin and the different ways of life. They cannot form a family or society; and this is also true for the modern man and woman because, in a way, the individuals are condemned to loneliness and isolated lives. Eddie is a man of action. This troublesome male creature wants to be untied, cannot lead a stable, calm life which May, the female is after. In contrast to him, May needs, as an emotional being, a home and a loyal husband. In a typical Shepard family, man is an outsider and woman is a domestic one. This contradiction which prevents their union reflects only one side of the coin. In this point, they come to an intersection: there appears May's date, Martin, a rural boy, and another woman, whom May calls "the Countess," who is seemingly very angry with Eddie, shoots and blows up his truck. Then, the end of the play as well as the meaning is blurred with the smoke of the blown truck.

Fool for Love coincides with the stormy period of women movement, feminism. Although women were not fully successful in what they were fighting for, an influential woman voice was
${ }^{11}$ Bigsby, ibid, p.170.

${ }^{12}$ Don Shewey, "Rock-and-Roll Jesus with a Cowboy Mouth," American Theatre, April, 2004, p.82. 
heard in several fields from politics to economics. And their struggle brought important achievements both in the 1960s and 1970s. Effective changes were felt in the roles and images of women. The widespread use of birth control devices, such as contraceptive pills, made it possible to control unwanted pregnancy and reproduction of the women, which provided them with more freedom and rights. The former mothers, who were only seen at home as mothers or housewives, took relatively crucial roles in making decisions. They were not a disadvantageous class anymore. They enjoyed political, economic and social rights. Lessening the burden at home, the women tried to have a balanced life between home and work. Not only in business, but in politics, sports and film industry they got major roles. All these improvements and media created a new model of woman who needed no support of man in life anymore. ${ }^{13}$

Fool for Love implies that the sexes have gender-related certain roles: the female is always helpless, the victim; the male is irresponsible and acts recklessly and ruthlessly. ${ }^{14}$ We get the impression that men and women alike are criticised in the play. As in the example of the Old Man and Eddie, the males do not behave honestly, and they deceive their counterparts. Visiting their female counterparts arbitrarily, the males are not reliable, so the self-criticism of the playwright is what we get from this message, too. As regards the females, they can easily be deceived or cannot control their feelings or relationships with men. Following the examples of men, reciprocally women also apply the cheating alternative using their sexuality. Consequently, there is no a single sex blamed, but both sexes are equally guilty for an unhappy relationship. In this way, bad behaviours become sort of universal facts. Both man and woman use their free will, the existential right to choose, and thus they are obliged to bear the responsibility of their free choices. And the outcome, of course, turns out to be a hard one, and even in some cases, a real catastrophe.

\footnotetext{
${ }^{13}$ Hall, ibid, p.91.

${ }^{14}$ Don Shewey, Sam Shepard, Da Capo Press, New York, 1997, 143.
}

Shepard focuses on the psychology of women, or with his terms, the female part of the human beings. He generally examines the 
clash between two males, and this conflict is mostly between a civilised and a wild one. With Fool for Love this male oriented conflict begins to be replaced by a conflict between a man and a woman. This shift coincides with the time when he puts an end to his marriage. Thus, Shepard develops an interest in the conflicts between the opposite sexes. He tells Bernard Weiner of The San Fransisco Chronicle about Fool for Love:

I was determined to write some kind of confrontation between a man and a woman, as opposed to just men. I wanted to try to take this leap into a female character, which I had never really done. I felt obliged to, somehow. But it's hard for a man to say he can speak from the point of view of a woman. But you make the attempt. ${ }^{15}$

A Lie of the Mind is Shepard's other play in which he handles gender conflict. The play opens with a telephone conversation between the brothers, Jake and his brother Frankie. This dialogue functions as an exposition which introduces the background of the play and prepares the audience for the coming events. From the conversation we are informed that Jake has beaten his wife, Beth, to death and he thinks that she is dead. The reason for Jake's anger is his jealousy, he thinks that Beth is not loyal to him, does not fulfil her duty at home and take his warnings into account. Furthermore, she does not wear as Jake wishes. Instead, she dresses in an immoral way, and becomes a destructive female, who is unfaithful to her husband.

In A Lie of the Mind, Hall argues, applying violence, Jake brutally beats Beth because he wishes Beth to act in accordance with his instructions, believing that she "has betrayed him through her body, so it is her body that must be punished."16 After Beth returns to her father's house, she has to choose a new life, with or without a man. Her mother proposes a choice to Beth. According to Hall, the mother's question concerning whether Beth wants boots or slippers is a symbolic one: these images are gender-related. ${ }^{17}$ Beth's reaction to this question is not clear at first because of her brain damage. But soon she gives the

${ }^{15}$ Ibid, p.142.

${ }^{16}$ Hall, ibid, p.111.

${ }^{17}$ Ibid, p.112. 
clues that she will again choose to live with a man since she has chosen male-identified images. For example, she wears her father's shirt and approaches Frankie for sexual implications: "You could pretend to be in love with me. With my shirt. You love my shirt...You fight but all the time you want my smell. You want my shirt in your mouth. You dream of it. Always. You want me on your face" (pp.81-82). Beth is in a half conscious state and gets a hysterical turn in tempting Frankie. Beth's attitude is man-like, she is seen in the shape of a man who is about to rape Frankie, who, in contrast to Beth, is now in a quasi-feminine role as if he becomes impotent. Hall concludes that, "Frankie is symbolically castrated; his leg has been shot, so he cannot move, and therefore cannot harm Beth." ${ }^{18}$ What Beth says to him contributes to this view: "You could be the woman...You are my beautiful woman" (p.81).

In A Lie of the Mind, Jake and Beth, in fact, are very similar characters. They both express their loves to one another. Shepard informs us that even their way of sleeping is identical (p.34). Both characters experience a bitter physical violence: Beth is beaten by Jake at the beginning of the play, and Jake is beaten by Beth's brother, Mike at the end of the play. They give trouble to a mutual relative, Frankie, Jake's brother, who acts as a mediator.

Their mothers each ignore the other spouse: Beth's mother ignores Jake, and Jake's mother ignores Beth, as Jake's mother, Lorraine says: "Who's Beth?...Never heard a' her" (p.28). Jake thinks that he has killed Beth who says that she has been killed. They sort of form a whole; each one is a part of that whole. However, their union is as problematic as their separation. Here the family institution and love are questioned.

The terms love and death and the connection between them are emphasized. There is a parallelism between Beth's marriage and her parents' marriage. 'Love' means killing for Beth's father, and Beth, who is loved by Jake, is beaten to death by him. Beth has a 
brain damage, and now she has been more emotional than ever before: “...This is me now. The way I am. Now. This. All. Different. I-I live inside this. Remember...I know-love. I know what love is. I can never forget. That. Never" (p.63).

Shepard tries to get an existential explanation for the nature of man and woman. He searches for the reasons why men tend to escape from home, and this inquiry is also for his father's escape from his family and responsibilities. As a result, Shepard concludes that both sexes are in need of each, while the female accepts, the male ignores it and escapes, but, in fact, does not know what he needs. This conflict afflicts and even kills the man, and only his death ends the problem as Meg, Beth's mother, points out, in A Lie of the Mind:

The female-the female one needs-the other...But the male one-doesn't really need the other. Not the same way...The male one goes off by himself. Leaves. He needs something else. But he doesn't know what it is. He really doesn't know what he needs. So he ends up dead. By himself" (p.111).

Lorraine, Jake's mother looks for an answer to this existential question, too: "Is there any reason in this Christless world why men leave women?"(p.92). She also makes a philosophical description of love: "Love! There's another disease....It's a disease that makes ya feel good. While it lasts. Then, it's gone, yer worse off than before you caught it" (p.98).

The violence and irresponsibility of man is not the only thing criticised, but Shepard is also angry with the females for their weakness and their feeling of inferiority. In one of the scenes, Beth wears man's shirt, like a child imitating the father and having a great desire to be like him. Meg, Beth's mother speaks of Beth as: "She's got male in her" (p.110). And Beth confesses that "Now, l'm like the man. Just feel like the man... like father... like brother" (p.81). Beth looks ridiculous, and she is not a good female example whether as a traditional or a challenging one. 
Shepard shows us how degrading men act in treating women, and this attitude never disappears whether there is love or not. Jake supposedly loves Beth but beats her to death. Beth's father, Baylor considers Beth's injuries less important than caring his mules. In the case of Jake, woman is turned into an object, one of the belongings, but in the second example, in the case of the father, the female is degraded more, to a much lower state. Beth's father is a marginal immoral type and a selfish male. His selfishness and hunger are above the tolerable levels. Abstract terms such as love, affection, or emotions have disappeared from his world: "This is my father. He's given up love. Love is dead for him. My mother is dead for him. Things live for him to be killed. Only death counts for him. Nothing else" (p.63). Women are nothing but servants to him. As soon as women obey him, he keeps them as he has kept his mules. But if they do not, then he may easily dispose them like wastes. This is really what happened to Beth's grandmother, as Beth recalls: "They cut her. Out. Disappeared. They don't say her name now. She's gone. Vanish. (She makes a "whooshing" sound like the wind). My father sent her someplace. Had her gone" (p.80). We come across another event which can be regarded as a family secret like that in Buried Child. And the secret is finally revealed at the end of the play. Such expositions remind us that the families generally have such secrets which remain uncovered, but wait to be deciphered sooner or later.

On the other hand, Baylor needs women as he needs other materials in order to survive. The continuation of his existence depends on the existence of women. Although Beth's mother realizes this cruelty, she keeps her silence and obeys her husband.

In A Lie of the Mind, although Jake beats his wife and leaves there thinking that she is dead, still he wants her back. In this and other plays woman is a sort of fetish, a material for man either to abuse or enjoy. The whole control is in the hands of the males. The male characters in the play have a goal while the females are aimless. As an example, Frankie tries to save Jake and end the 
disagreement between the spouses and others by mediating; Mike seeks to take revenge on Jake; and Jake wants Beth back. In contrast to the male characters who have certain goals, Beth has nothing to go after since her brain has been damaged; furthermore, she is weak and poses a childish attitude.

Lorraine wants her daughter, Sally to leave home. And thus, she will be able to live with her son, Jake. She cares for him, believing that he is her most important off-spring. She is a typical woman who gives utmost importance to male off-springs because she is a male-dependent female. Such an excessive care and love for son reminds us another implied incestuous affair. As Hall puts it: "Again, the incestuous relationship between mother and son is hinted at. However, Jake has already won oedipal battle since he has killed his father on a drinking expedition." ${ }^{19}$ Sally tells her mother how Jake killed the father in an allegorical way, as if telling a different story. Lorraine seems to be influenced by the story and begins to realize what has happened for ages, and now she seems to be awakened after a long period of hibernation-like sleep, developing anger and hatred for the male households:

I know one thing for sure. All these airplanes have gotta go...Every last one of 'em. All the junk in this house that they left behind for me to save. It's all goin.' We'll make us a big bonfire. They never wanted it anyway. They had no intention of ever comin' back here to pick it up. That was just a dream of theirs. It never meant a thing to them. They dreamed it all up just to keep me on the hook. Can't believe I fell for it all those years (p.102).

Lorraine wishes to get her freedom and put an end to anything reminding her of males after all those years of captivity by setting a "bonfire." The women in Shepard's works are treated like objects and have been detained, so they are fed up with it in the end. And his male characters resemble one another in treating women. More or less the portraits of males are similar, and they are brutal creatures. Shepard's female characters are portrayed in a way that they must obey; or else, they are annihilated or ${ }^{19}$ Hall, ibid, p.114. repressed by the males. 
At the end of the play Jake is humiliated by being forced to move around on his hands and knees, chained and enslaved by Beth's hatred-seeking brother. In a way, violence in Shepard's plays continues throughout the play, and the sufferer subjected to violence is everybody. Even the oppressor, Jake, turns out to be the sufferer. Suffering is something equal to the life itself. Although the destructing agent is the male, the constructing subject is again the male, and in each action female only has a limited role. Man is always in action, he is the active one. Although the playwright destructs the traditional way of drama and style, he clings to the male dominated literature. Shepard's characters, women or men, need to be pitied because they are real contemporary individuals.

With the play, The States of Shock, the author focuses his attention on men who are exploited, crippled or even killed either literally or figuratively. The role of the woman in this play, as in A Lie of the Mind, is a restricted one. She only watches an already dysfunctional world of frustrated men. The males seem to be lost in a bleak atmosphere. In Shepard's plays, as Bigsby argues: "the American male is cut off from a past in which the national story gave him a central position and adrift in a present in which he is unsure of his role." 20

${ }^{20}$ Bigsby, ibid, p.193.

${ }^{21}$ Fulcher, ibid, pp.394-5.

Violence represents male's weakness in a way and it appears in different forms in Shepard's plays. Rape is an example for this violence. The definition of rape is not limited only with forced intercourse or attempt, but also includes broader situations of any kind of forced sexual approaches. ${ }^{21}$ In Buried Child, Shelly is symbolically raped by Bradley, which is also an indication of various sexual abuses in a family, either between spouses, children or other relatives. In the play Shelly is an outsider, an audience as we are. Through her analysis we get the verification that not only we have a negative impression, but also Shelly has the same feelings. Her position is similar to that of Rosencrantz and Guildenstern in Tom Stoppard's Rosencrantz and Guildenstern are Dead in that she is both an audience and an actor in the play. We share a common point of view with Shelly, 
who is disappointed, like us, at the sight of such an unpleasant and alienated family. Except from Shelly, all other characters are caught up in a dead system composed by people of the same poisoned blood like the 'cursed' Tate family in the Curse of the Starving Class. ${ }^{22}$

Simpatico (1993) is another play in which Shepard treats female characters in a degrading way. The main characters are two men: Carter and Vinnie. Carter has everything one can have; he not only possesses materials but women as well. He might easily run away with a married woman (Rosie) or have another woman (Cecilia) do his dirty deeds. The two female characters Rosie and Cecelia can easily be tempted when money matters. Again female characters are seen as simple and unimportant creatures like material objects. Except from the final scene in which Cecelia hurls Carter's money, we do not even get the slightest implication that the female characters show any resistance or rejection showing their personal choice or independence. The play is constructed on the rivalry of the two men while the women are given only complementary roles as in most Shepard plays. They are either run off or hired by the males.

Lynda Hart stresses that critics, such as Florence Falk, criticise Shepard for the absence of women in his plays and for that the playwright seems to speak from a masculine perspective and the world he portrays is deprived of women. ${ }^{23}$ Travis, in Paris, Texas, like Shepard's most characters, inherits and continues his father's fault. Travis tells his son, Hunter that, in fact, he has never seen his mother though he has looked at her. In Shepard's most plays, the existence of the female characters is not felt because they take passive roles. For example, the mother, in True West, is the absent female character who has left for Alaska. She is both literally and figuratively absent. As soon she appears, she disappears again although the setting of the play is her house. On the other hand, the males in the play engage in a kind of duel, fight, break, smash and hit each other proving their masculinity. In contrast with the ineffectiveness of the female, the male is ${ }^{23}$ Hart, ibid, p.69. quite active, but this action is a destructive one. 
Hall argues that the reason lying beneath chasing males each other, in Paris, Texas, is the motivation caused by the absence of the females, and the writer adds:

Shepard's image very poetically summarizes Lacan's theories regarding the essential lack that characterizes human existence. Without presence of a woman, the men are lost, ostensibly defending their rights, but finally the chase creates the illusion of some sort of meaning to their meaningless existence. ${ }^{24}$

Having returned from England, Shepard's work takes a new form and direction. Family becomes the main subject in his plays, as in Curse of the Starving Class, which parodies paradoxical and simple female characters. In this play, the family is innately a cursed one. Therefore, the households in the family are left incapable of loving. Hall likens this curse to the "curse of menstruation, and the play represents such blood as somehow defiled." ${ }^{25}$ Thus, not only the father's blood is blamed for being the source of curse and the inability to love, it is also implied that the female contributes to this disease within the house. We witness again an oedipal situation at the end of the play because the son, getting rid of the father and sister, remains as the only male at home with the mother, which also recalls an incestuous affair.

In his later plays, unlike the earlier ones, Shepard writes plays favouring woman characters confusing the feminist critics for what they had written about him before. He makes fun of male violence and even shows a remarkable sympathy with his female characters. Female characters represent reason in stark contrast with the absurdity and recklessness of the male characters. Furthermore, man destroys and spoils anything around him as an incapable, impotent creature. Female characters play an important role only in these later plays. He not only portrays stereotypical female characters, but also, to some extent, challenging and

${ }^{24}$ Hall, ibid, p.104.

${ }^{25}$ Ibid, p.94. effective ones. For example, contrary to his earlier works, In Motel Chronicles, the playwright draws the picture of a man who is too dependent upon his only woman to leave. 
Shepard is regarded as a playwright who likes to convey his private life in his plays. Shepard's two opposite attitudes towards woman in his plays coincides with his living with different women in different times, so it is quite possible that this situation reflects his real family life. And this idea is not a groundless one, for Shepard is known as a playwright, like most existential novelists, or absurd playwrights, who reflects his psychology in his works. While his early plays, which show disrespect and hatred for women, coincide with his marriage to O-Lan, his later plays showing sympathy for women coincides with his later life with Jessica Lange for whom he left his wife O-Lan and his son. Don Shewey suggests that the playwright reflects his strong feeling of emotional pain of guilt for the way he has treated the women in his life:

Perhaps he felt guilty about abandoning one woman for another and sought to dramatize his emotional turmoil. It's possible, though, that Fool for Love and A Lie of the Mind represent as much of an inner conflict as, say, True West and that the abused women he's writing about are part of his own psyche. ${ }^{26}$

His ideas about women traces back to his childhood and to the relationships with his mother long before those with the other women. Observing his face in front of a mirror, he feels that his right eye was more open than his left eye, believing that the good one comes from the mother while the smaller bad one from the father. Identifying the better one with mother, the female and the worse with father, the male characterizes many of his later plays. That is why his early plays pose a hostile attitude, but the later ones a friendly one towards women. Some critics associate his later approach with an oedipal situation. ${ }^{27}$

\section{Conclusion}

Shepard is criticised by some feminist critics for giving trivial roles to the women and for humiliating female characters, and they make it clear that Shepard's plays ignore women, their capabilities, and achievements in general. They argue that using male violence in abundance, which is the typical style of Shepard, 
is a clear sign for this claim. ${ }^{28} \mathrm{He}$ seems to take pleasure from this violence. And often magazines portray him as 'Marlboro Man' because of this and his cowboy style. Particularly in his early plays, he gives rather passive roles to female characters. This is considered to be underestimating females, and looking from a male perspective. Women are seen to act only as secondary or supporting characters to the males.

Mothers are torn between fathers and sons as a result of a sort of oedipal impact. Halie, in Buried Child, who bears an incestuous child from his son Tilden, is a typical example of this ongoing rivalry. His heroes are marginal characters placed in unusual settings. His plays are criticised for including several elements of misogyny or gynophobia. ${ }^{29}$ Shepard's male characters always seek to run away from women who try to survive depending upon males. The female character in his plays is weak, dependent, problematic, discredited, and missing in every way.

In Shepard's plays, violence somewhat continues throughout the play, and almost every character in turn becomes sufferer subjected to brutality. Even the tormentors turn out to be the victim of violence. Therefore suffering becomes something equal to everyday life. While man assumes a destructing role, the constructing agent is again the male. In either way, female's role is a limited one.

${ }^{28}$ Shewey, Sam Shepard, ibid p.100.

${ }^{29}$ Hall, ibid, p.92.
In conclusion, the playwright deals with the marital violence and makes suggestions about the reason for male violence. The destructiveness of violence is emphasized in most of Shepard's plays. Shepard is regarded as a playwright who likes to convey his private life in his plays. The problematic father image reflects clearly the playwright's memory concerning his real life experience. Shepard's two opposite attitudes towards woman in his plays coincides with his living with different women in different times, so it is quite possible that this situation reflects his real family life. 
MAN, WOMAN, VIOLENCE AND SAM SHEPARD

\section{References}

Bigsby, C. W. E., (2000), Modern American Drama, 1945-2000, The Press Syndicate of the University of Cambridge, UK.

Boehnlein, James K., Susan S. Erstling and Landy F. Sparr, (1990), "Sam Shepard and the Dysfunctional American Family: Therapeutic Perspectives," American Journal of Psychotherapy, Vol. XLIV, No.4, Oct, 1990.

Bressler, Charles E., (2003), Literary Criticism: An Introduction to Theory and Practice, Upper Saddle River, New Jersey.

Fulcher, James and John Scott, (1999), Sociology, Oxford University Press.

Hall, Ann C., (1993), A Kind of Alaska: Women in the Plays of O'Neill, Pinter, and Shepard, Southern Illinois University Press, Carbondale.

Hart, Lynda, (1988), "Sam Shepard's Pornographic Visions: Depictions of Women in his Plays," Studies in the Literary Imagination 2: 69-82.

Shewey, Don, (1997), Sam Shepard, Da Capo Press, New York.

---------, (2004), “Rock-and-Roll Jesus with a Cowboy Mouth,” American Theatre, April, 2004.

Shepard, Sam, (1996), "A Lie of the Mind" in Plays: 3, Methuen Drama, London.

--------, (1990), "Buried Child" in Seven Plays, Faber and Faber, London-Boston.

(1990), "Curse of the Starving Class" in Seven Plays, Faber and Faber, London-Boston.

बैैซอ? 